Dr RANKA GAŠIĆ, viši naučni saradnik

Institut za savremenu istoriju

Beograd, Trg Nikole Pašića 11

rankagasic@gmail.com

UDK 30.342:711.4(497.11)"1953/1991"

originalan naučni rad

629.33:711.4(497.11)"1953/1991"

primljeno: 11. april 2016.

316.334.56:711.4(497.11)"1953/1991"

prihvaćeno: 18. maj 2016.

\title{
FABRIKA I GRAD: URBANI RAZVOJ KRAGUJEVCA POD UTICAJEM AUTOINDUSTRIJE 1953-1991.*
}

APSTRAKT: $U$ članku je reč o urbanom razvoju Kragujevca pod uticajem naglog razvitka automobilske industrije, koji se pokazao u višestrukom uvećanju broja stanovnika, promeni strukture grada od jednog urbanog naselja ka urbanoj aglomeraciji, i novom tipu gradnje stambenih naselja radi rešavanja stambenog pitanja zaposlenih u industriji.

KLJUČNE REČI: Kragujevac, automobilska industrija, „Crvena zastava“, urbanizacija

Kragujevac ima istorijski kontinuitet od sredine 19. veka kao industrijski grad, centar vojne industrije iz koje se polovinom 20. veka razvila i automobilska industrija. Kada je reč o uticaju automobilske industrije na razvoj privrede i društva, ne može se zaobići i njen ogroman uticaj na industrijalizaciju i urbanizaciju na području cele Jugoslavije. Kragujevac, kao domicilni grad Zavoda „Crvena zastava“, upravo je najbolji primer koliko je ta industrija uticala na preobražaj grada i promenu načina života njegovih stanovnika i okoline. Istovremeno, ovaj proces ima i svoju političku dimenziju, koja se očituje kroz promene administrativno političkog statusa grada i opštine, kao i međusobnog odnosa tri aktera: opštinskih vlasti, rukovodstva Zavoda "Crvena zastava“ i viših državnih instanci.

U svom istorijskom razvoju, Kragujevac je bio balkanska varoš, zatim prestonica autonomne srpske kneževine, a tek kasnije se razvio $\mathrm{u}$ industrijski centar. On, dakle, nije nastao kao naselje vezano isključivo za

* Rad je deo projekta Srpsko društvo u jugoslovenskoj državi u 20. veku: između demokratije i diktature (177016), koje finansira Ministarstvo prosvete, nauke i tehnološkog razvoja Republike Srbije. 
industrijsko preduzeće (Vojnotehnički zavod, a kasnije Zavode „Crvena zastava"), kao što je slučaj sa tzv. company town u razvijenim industrijskim zemljama. ${ }^{1} \mathrm{~S}$ druge strane, iako je u drugoj polovini 20 . veka bio prevashodno industrijski grad i pravi primer socijalističke industrijalizacije i urbanizacije, nije bio novo naselje, nastalo isključivo kao socijalistički eksperiment (kao npr. Dimitrovgrad u Bugarskoj²), već grad sa dugom istorijom. Zapravo, politički razlozi, to jest status političkog centra autonomne Srbije, uslovili su lociranje vojne industrije na tom mestu, koja je zatim postala lokomotiva razvoja ukupne industrije u Srbiji, i samog grada Kragujevca, u narednih sto godina (1853-1953). ${ }^{3} \mathrm{U} 19$. veku premeštanje prestonice $\mathrm{u}$ Beograd nije uticalo na premeštanje vojne industrije, koja je ostala u Kragujevcu iz strateških razloga. Kada je, međutim, vojna industrija razmeštana po drugim centrima Jugoslavije posle Drugog svetskog rata, početak automobilske industrije u Kragujevcu omogućio je ne samo opstanak mnogih radnih mesta $u$ industriji, već i kontinuitet industrijskog karaktera grada. I više od toga, razvoj Zavoda "Crvena zastava" $u$ industrijski gigant tadašnje države direktno je uticao na razvojni bum grada kao moderne urbane aglomeracije. Industrija je, dakle, od početka moderne srpske države u 19. veku bila u Kragujevcu osnovna gradska delatnost.

Vojna industrija je od 19. veka prostorno bila blisko povezana sa gradom, kao sastavni deo novog državnog centra. U periodu od 1818. do 1841, kada je grad postao prestonica autonomne Kneževine Srbije, izgrađen je dvorski kompleks i upravna zona na desnoj obali Lepenice, preko puta starog jezgra grada. Tu su podignuti Arsenal (1833), a kasnije i druge zanatske radionice - kovačnica i bravarnica 1841, i Fabrika za vojnu spremu 184547. Uz Arsenal, podignuta je 1850. Topolivnica, pored niza vojnih objekata Stare kasarne. Ovaj vojni kompleks, kasnije prerastao u Vojno tehnički zavod (VTZ), iako tesno prostorno povezan sa gradom, bio je nepristupačan za civile,

${ }^{1}$ Port Sunlight (1888) i Bournville (1895) u V. Britaniji predstavljaju tipičan model „company town“, grada koji nastaje uz neku veliku industriju ili korporaciju. Sličnih primera ima u SAD, Nemačkoj, Poljskoj, Švedskoj, ali i u Ukrajini i Slovačkoj. (Company town, https://en.wikipedia. org/wiki/Company_town, (pristupljeno 5. 4. 2016).

${ }^{2}$ Videti: Ulf Brunnbauer, „Dimitrovgrad. Eine sozialistische Stadt in Bulgarien“, in: Urbanisierung und Stadtentwicklung in Suedosteuropa vom 19 bis zum 21 Jahrhundert, hrsg. von Thomas M. Bohn und Marie Janine Calic (Muenchen-Berlin: SuedosteuropaGesellschaft, 2010), 197-221.

${ }^{3}$ Vojska po pravilu predstavlja snažan faktor modernizacije i motor sveukupnog razvoja države u zemljama tzv. zakasnele modernizacije. O tome videti: Manfred Halpern, „Middle Eastern Armies and the New Middle Class", in: The Role of the Military in Underdeveloped Countries, ed. John Johnson (Princeton (NJ): Princeton University Press, 1959), 277315; Mile Bjelajac, „Vojska kao faktor modernizacije“, u: Srbija u modernizacijskim procesima 20. veka (Beograd: Institut za noviju istoriju Srbije, 1994), 355-359. 
kao „grad i gradu“. ${ }^{4}$ Istovremeno, izgradnja dvorskog kompleksa i upravne zone sa vojnim objektima s druge strane reke, odredila je budući razvoj grada duž kraljevačkog druma. ${ }^{5}$ U poslednje tri decenije 19. veka javljaju se počeci industrije u Srbiji. Sticanje nezavisnosti 1878, Zakon o povlasticama industrijskim preduzećima iz 1873, i otvaranje Berze 1895. stvorilo je okvire za razvoj fabričke industrije. ${ }^{6} \mathrm{U}$ vezi s tim, počinje i moderan urbani razvoj Kragujevca, koji se transformiše od orijentalne varoši, bez moderne komunalne infrastrukture, ka evropskim uzorima u urbanizmu i arhitekturi. U tu svrhu, podignut je i prvi opštinski zajam. Od sredine 19. veka do Prvog svetskog rata u Kragujevcu je osnovano sedam banaka i devet industrijskih preduzeća. ${ }^{7}$ Tako je 1887. usledila i velika rekonstrukcija VTZ-a, u koju je uloženo oko 3,5 miliona dinara. Ovaj novi razvojni ciklus fabrike vodio je inženjer Todor Selesković. ${ }^{8}$ Novi kapaciteti izgrađeni su po nemačkim uzorima, a predstavljali su i pravu revoluciju u izgradnji moderne infrastrukture grada. Za potrebe VTZ-a izgrađena je električna centrala sa sistemom osvetljenja 1884, a sledila je izgradnja Trmbaskog vodovoda (pušten u rad 1904), kao i železničke pruge od Lapova do Kragujevca 1886. Grad je 1892. dobio i gvozdeni most, umesto starog, kamenog mosta. ${ }^{9}$ Modernizacija i razvoj ove fabrike direktno su podstakli urbanizaciju i donošenje prvog urbanističkog plana - Plana regulacije varoši Kragujevca inženjera Luke Ivkovića iz 1891. Međutim, planiranje grada i fabrike, zbog njenog vojnog karaktera, bili su odvojeni. ${ }^{10}$ Demografski rast i prostorno širenje grada bili su prirodna posledica ovog prvog velikog investicionog ciklusa VTZ-a i reorganizacije fabrike koju je izvršio inž. Todor Selesković. Fabrika je od nekoliko stotina zaposlenih u 1878. narasla na preko 2000, do 1920-ih godina. Kragujevac je 1878. imao 7.500 stanovnika, a do 1920-ih godina dostigao je već 20.000 , čime je ušao u red gradova srednje veličine.

${ }^{4}$ Верољуб Трифуновић, Урбанизам Країујевиа. 20. век. Књиі̄a йрва. Периоg оg 1878. go 1974 (Крагујевац: Дирекција за урбанизам и изградњу Крагујевца, 2004), 239.

${ }^{5}$ Vladimir Macura, Čaršija i gradski centar: razvoj središta varoši i grada Srbije XIX i prve polovine XX veka (Niš-Kragujevac: Gradina-Svetlost, 1984), 68.

${ }^{6}$ Isto, 51.

${ }^{7}$ В. Трифуновић, н. g., 231; Драгољуб Бакић, Пей векова Країујевца. Члании и усйомене. Превоgи и ирреииска (Крагујевац, 1972), 145, 152.

${ }^{8}$ В. Трифуновић, н. g, 227. Inženjer Todor Selesković (Beograd, 1856 - Kragujevac, 1901), profesor Tehničkog fakulteta Velike škole u Beogradu i osnivač proizvodnog mašinstva u Srbiji. Poznat je kao projektant vojne industrije u Kragujevcu, ali i kao konstruktor alatnih mašina, hidroelektričnih i parnih centrala, i kao profesor mehaničke tehnologije. (Тодор Селесковић, https://sr.wikipedia.org/sr/Тодор_Селесковић, (pristupljeno 5. 4. 2016).

${ }^{9}$ В. Трифуновић, н. g., 230; Д. Бакић, н. g., 196, 150-151. O vodovodu videti takođe: Живомир Спасић, Век усйона Країујеви,а. Прилози исйорији ірраgа и околине (Крагујевац: Светлост, 1978), 273-278.

${ }^{10}$ В. Трифуновић, н. g., 231, 241. 
Prvi urbanistički plan Kragujevca predvideo je budući rast do 25.000 stanovnika, i bio je ostvaren 90\%. Građevinski rejon Kragujevca 1878. u ovoj fazi nije bio značajno proširen - od nešto manje od 200 ha, 1920-ih dostigao je 250 ha. $^{11}$

Posle Prvog svetskog rata pokrenut je novi ciklus investicija u razorenu i oštećenu fabriku, a usvojena je i nova koncepcija njenog razvoja, u periodu od 1923. do 1928. Razdoblje posle Prvog svetskog rata do ekonomske krize 1929. bilo je inače vreme obnove i građevinskog buma u Beogradu i drugim jugoslovenskim gradovima. ${ }^{12}$ Tada je VTZ proširen na površinu od preko 55 ha, po projektima belgijske firme, a izgrađeni su palata Uprave VTZ i blok Vojnozanatske škole, kao i Radnička kolonija izvan gradskog rejona. Iz ovog ciklusa investicija proizašlo je dalje ulaganje u infrastrukturu: regulacija Lepenice i izgradnja mostova, železničke pruge za Mednu i za Kraljevo, Grošnički vodovod (akumulaciono jezero u selu Grošnici) i asfaltni put za Beograd. Sve ovo stvorilo je potrebu za novim Generalnim planom grada, koji je rađen od 1931. do 1935. VTZ je bio ograđen zidom i odvojen od grada, i u smislu planiranja. Dok je grad bio planiran po francuskom uzoru, fabrika je bila planirana po belgijskom. Struktura fabrike, međutim, nije bila obuhvaćena tim planom, zbog njenog vojnog karaktera, već je planirana samo Uprava Zavoda i Vojnozanatska škola. ${ }^{13}$ U gradu je već 1920 -ih bila velika koncentracija radnika i tehničkih stručnjaka. Od tada do početka automobilske industrije sredinom 20. veka, grad je narastao sa 20.000 na oko 50.000 stanovnika, dok je građevinski rejon proširen sa 250 ha na 2000 ha. Podignuti su neki objekti od značaja - gimnazija, nova crkva, sud, železnička stanica, vojne zgrade i blokovi u centru. ${ }^{14}$ Generalni plan arhitekte Mihajla Radovanovića 1931-1935. predvideo je, prema tadašnjem tempu razvoja grada i vojne industrije, da će Kragujevac 1961. imati 55.000 stanovnika, a 1981. godine $75.000 .{ }^{15}$ Razvoj je, međutim, usled rata i kasnije pojave automobilske industrije krenuo sasvim različitim tempom. VTZ je u Drugom svetskom ratu bio ponovo porušen.

Tokom perioda socijalizma, Kragujevac je više puta menjao status u administrativno-teritorijalnoj podeli zemlje. Od 1949. do 1952. imao je

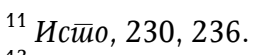

12 O tome: Draga Vuksanović Anić, „Urbanistički razvitak Beograda u periodu između dva svetska rata (1919-1941)“, u: Istorija 20. veka, Zbornik radova IX (Beograd: Institut za savremenu istoriju, 1968), 447-510; Ranka Gašić, „Urbanizacija međuratnog Beograda. Primer naselja 'Kotež Neimar'“, Istorija 20. veka, br. 2, (2009), 53-66; Ista, „Problemi teritorijalnog širenja Beograda između dva svetska rata“, Istorija 20. veka, br. 3, (2010), 57-68.

\footnotetext{
${ }^{13}$ В. Трифуновић, н. g., 242.

${ }^{14}$ Истио, 230-231.

${ }^{15}$ В. Трифуновић, н. g., 236.
} 
značajnu funkciju kao centar šumadijsko-raške oblasti. Od 1955. u Jugoslaviji je uveden tzv. komunalni sistem, koji je podrazumevao decentralizaciju i prebacivanje nekih bitnih ingerencija u nadležnost opština i gradova. ${ }^{16}$ Tada je Kragujevac postao središte sreza, obuhvativši i bivše srezove kragujevački, lepenički i gružanski, od 1957. i opštine Topolu i Aranđelovac. Tokom 1960-ih godina, (od 1963. do 1967) bio je središte sreza sa dvanaest opština i oko 500.000 stanovnika. Kada su srezovi ukinuti 31. marta 1967, grad je postao centar opštine sa oko 140.000 stanovnika i 65 naselja. Konačno, u periodu od 1976. do 1989. bio je centar regionalne zajednice Šumadije i Pomoravlja, sa 550.000 stanovnika i 12 opština. Ustavom iz 1989. regioni su ukinuti, pa je tada postao centar Šumadijskog okruga koji su činile opštine Aranđelovac, Batočina, Knić, Kragujevac, Lapovo, Rača i Topola. Godine 1992. dobio je status grada, pored Beograda, Novog Sada i Niša. ${ }^{17}$

Ubrzani razvoj kragujevačke industrije i samog grada počinje 1960ih godina, izgradnjom fabrike (1962) i početkom masovne proizvodnje putničkih automobila. Kragujevačka industrija ušla je time u svetsku privredu i međunarodnu podelu rada, sa najvećom fabrikom automobila u jugoistočnoj i srednjoj Evropi. Tempo razvoja grada u naredne dve decenije dobio je ogromno ubrzanje. Stanovništvo je naraslo sa 50.000 na preko 100.000 tokom 1970-ih, čime je Kragujevac izašao iz kategorije srednjih gradova. ${ }^{18}$ Sredinom 1970-ih, $80 \%$ privrednog potencijala grada predstavljala je upravo "Crvena zastava". ${ }^{19}$

Velike investicije $\mathrm{u}$ fabriku, to jest u kompleks Zavoda „Crvena zastava“, intenzivne posebno tokom 1960-ih i 1970-ih, pokrenule su urbani razvoj grada i stambenu izgradnju takvog intenziteta da su urbanistički planovi uvek zaostajali za stvarnošću. Fabrika je potpuno promenila grad. Od 1954. do 1962. proizvodnja automobila odvijala se u krugu predratnog Vojnotehničkog zavoda. Prema Generalnom urbanističkom planu iz 1961, koji je rađen tokom 1950-ih, kompleks fabrike trebalo je da ostane u postojećim granicama, sa maksimalnim brojem zaposlenih do 12.000. Kako je proizvodnja automobila prevazišla sva očekivanja nadležnih u gradu i republici, došlo je 1962. do izgradnje nove fabrike na Abisinskom polju, na ukupnoj površini od 45 ha, za godišnju proizvodnju od 32.000 putničkih vozila. To je već bilo izvan okvira postojećeg generalnog plana. Pored 60 ha fabričkog zemljišta, zauzeto je trostruko više novog zemljišta na Abisinskom

${ }^{16}$ Dušan Bilandžić, Historija Socijalističke Federativne Republike Jugoslavije. Glavni procesi 1918-1985 (Zagreb: Školska knjiga, 1985), 229-231.

${ }_{17}^{17}$ В. Трифуновић, н.g., 143.

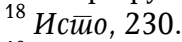

19 „'Zastava' u centru pažnje“, Ekonomska politika, 25. 10. 1976. 
polju, od Ždraljice do Grošničke reke. U zoni prateće industrije, severoistočno od gradskog jezgra, Zavodi su se 1960-ih godina proširili na četiri lokacije od ukupno 23,5 ha, na kojima su izgrađeni objekti od oko $49.000 \mathrm{~m}^{2}{ }^{20}$ Već 1965. fabrika je proširila kapacitete za proizvodnju do 45.000 automobila, a 1970. proizvodilo se i do 70.000 godišnje, $u$ halama ukupne površine od $80.000 \mathrm{~m}^{2}$. Naredna decenija predstavlja vreme najdinamičnijeg razvoja industrije Kragujevca. ${ }^{21}$ Tzv. druga faza razvoja fabrike koja je trajala između 1970-1972. donela je $130.000 \mathrm{~m}^{2}$ novog radnog prostora, kapacitet proizvodnje porastao je na 170.000 vozila, a uz međunarodnu kooperaciju i do 200.000 automobila godišnje. Uloženo je više od 130 milijardi dinara. Pored ogromnih skokova u kvantitetu i asortimanu robe, u kompleks kragujevačke fabrike stigli su, posredstvom „Fiata“, italijanski prostorni obrasci moderne industrije. Izgrađena je nova upravna zgrada fabrike, po ugledu na zgradu Pirelli iz Milana iz 1958, samo nekoliko godina kasnije. ${ }^{22}$ Time je ovaj grad ušao u svetske tokove hipermoderne internacionalne arhitekture. Sve ovo je uticalo i na drugačija predviđanja budućeg razvoja. Tada je planiran i razvoj treće faze auto-industrije. Tome je bila namenjena lokacija od oko 300 ha na Kormanskom polju. Urbanističkim planom „Kragujevac 1974-1977“, to jest izmenama i dopunama GUP-a, bilo je predviđeno 485 ha terena za automobilsku industriju, od čega je već dve trećine bilo izgrađeno. ${ }^{23} \mathrm{Na}$ lokaciji Zavoda "Crvena zastava“ 1980. godine bilo je oko $600.000 \mathrm{~m}^{2}$ izgrađene fabričke površine, na prostoru od oko 200 ha (terena nekadašnje Topolivnice koja se sada nadovezivala na gradski centar), sa oko 30.000 zaposlenih. Od te površine, oko 65 ha zauzimala je vojna industrija, a automobilska se prostirala na novih 135 ha. $^{24}$

\section{Projekcije o rastu stanovništva - nesklad između planova i stvarnosti}

Rast broja zaposlenih u industriji i stanovnika u gradu i okolini bio je tokom 1960-ih i 1970-ih mnogo brži od zvaničnih predviđanja. Prema GUP-u iz 1961. bilo je predviđeno da do 1981. u privredi bude 15.000 zaposlenih, a već krajem iste 1961. godine taj broj je bio premašen. ${ }^{25}$ Tada je

${ }^{20}$ Трифуновић, н. g., 208.

21 Табела бр. 15, Развој аутоиндустрије, В. Трифуновић, н. g., 245: 1953 - 162 vozila i 4.640 zaposlenih; 1961 - 14.972 vozila i 8.030 zaposlenih, 1971 - 79.955 vozila i 22.903 zaposlenih, 1981 - 194.827 vozila i 48.867 zaposlenih, 1991 - 108.160 vozila i 52.000 zaposlenih. Maksimalna proizvodnja vozila bila je 1989. (230.570), a tokom 1990-ih počinje opadanje usled raspada zemlje (tržišta) i međunarodnih sankcija.

B. Трифуновић, н. g., 170; Pirelli Tower, https://en.wikipedia. org/wiki/Pirelli_Tower (pristupljeno 5. 4. 2016).

${ }^{23}$ В. Трифуновић, н. g., 208, 248.

${ }^{24}$ Ис $\bar{u} 0,206$.

${ }^{25}$ В. Трифуновић, н. g., 165. 
ukupno zaposlenih bilo 22.661, a od toga u industriji $12.266 .^{26}$ Do 1981 , broj zaposlenih $u$ industriji bio je 26.884 , a do 1991. dostigao je 35.796 . $^{27}$ Tokom ovog perioda (od 1950-ih do 1990-ih), broj stanovnika u Kragujevcu porastao je od 40.615 u 1954 , do 87.764 tokom $1989 .{ }^{28}$ Popis stanovništva iz 1991. uzeo je u obzir celu gradsku aglomeraciju, to jest sva naselja koja su dotle srasla sa gradom, pa je broj stanovnika samog grada Kragujevca te godine iznosio čak $144.608 .{ }^{29}$ Do 1984. projekcije su bile da grad dostigne 85.000 stanovnika, sa krajnjim limitom od 100.000 , a da se u fabrici proizvodi 300.000 automobila godišnje. ${ }^{30}$ Projekcije u Urbanističkom planu iz 1965, bazirane na dotadašnjem vrtoglavom usponu, izašle su zapravo iz okvira realnosti. Po njima je trebalo da 1984. godine grad ima oko 120.000 stanovnika, od toga 50.000 u satelitskim naseljima, da u fabrici radi 50.000 radnika i da se proizvodi 500.000 automobila godišnje. ${ }^{31}$ Te godine, međutim, u industriji Kragujevca bilo je zaposleno 26.760 ljudi. ${ }^{32}$ Broj stanovnika odgovarao je ovim projekcijama (1984. bilo je 170.859 stanovnika, što je obuhvatalo grad i okolna naselja). ${ }^{33}$ Kapaciteti jugoslovenske automobilske industrije, međutim, nisu mogli realno da dostignu proizvodnju od 300.000 automobila godišnje, kako se u Zavodima „Crvena zastava“ očekivalo, čak i pod najboljim uslovima (granica od 200.000 automobila godišnje nije mogla nikada biti prevaziđena). ${ }^{34}$ Prema tom prilično nerealističnom planu, trebalo je izgraditi stanove za novih 70.000 stanovnika u centru grada (oko 37.000 stanova u periodu od 20 godina), i radi te izgradnje raseliti 35.00040.000 stanovnika. $^{35}$

Od osnivanja automobilske industrije 1953, a posebno od njenog naglog uspona početkom 1960-ih, planiranje grada nije moglo da prati tempo razvoja. To postaje sasvim jasno kada se uporede različiti urbanistički planovi grada tokom 20. veka, njihovo trajanje i sprovođenje u praksi.

${ }^{26}$ Tabela 6-2, Zaposleno osoblje u društvenom sektoru po delatnosti, Statistički godišnjak Jugoslavije (dalje: SG), 1961.

27 Tabela 4-1. Radnici u društvenom sektoru i delatnostima, SG 1981; Tabela 4-2 Radnici u društvenom sektoru i delatnostima, SG 1991.

28 Tabela 342, Srezovi i gradovi, SG 1954; Tabela 4-1, osnovni podaci o gradovima sa 20.000 i više stanovnika, prema popisu 1981, SG 1989.

${ }_{29}$ Demografija Kragujevca, https://sr.wikipedia. org/sr/Демографија_Крагујевца, (pristupljeno 5. 4. 2016).

${ }^{30}$ В. Трифуновић, н. g., 178.

${ }^{31}$ Ис $\bar{u} 0,179$.

32 Tabela 4-1, Radnici u društvenom sektoru po zanimanjima, SG 1984.

33 Demografija Kragujevca, https://sr.wikipedia. org/sr/Демографија_Крагујевца, (pristupljeno 5. 4. 2016).

${ }^{34}$ Слободан Јанковић, Зайиси о Застиави. Повоgом 140 їоguна раgа и 40 їоguна йроизвоgюе ауйомобила (Крагујевац: Застава, 1993), 114-115.

${ }^{35}$ В. Трифуновић, н. g., 183. 
GUP iz 1931-1936. važio je do 1961. godine, kada je usvojen novi plan, koji je u praksi sprovođen i pre nego što je zvanično usvojen. ${ }^{36}$ Krajem 1964. SO Kragujevca je odlučila da pokrene postupak za izmenu i dopunu GUP-a i za izradu prostornog plana opštine. Polazne osnove su bile da se stimuliše urbanizacija u susednim opštinama (Knić, Stragari, Batočina, Rača, Topola) da se tamo grade pogoni autoindustrije i time spreči preveliki pritisak na grad. ${ }^{37}$ Kada je 1965. usvojen Urbanistički program, istovremeno sa novim Zakonom o urbanističkom i regionalnom poslovnom planiranju, važeći GUP iz 1961. stavljen je van snage. Tako u vreme najintenzivnijeg razvoja fabrike (od 1950-ih do 1970-ih) grad nije imao uopšte važeći urbanistički plan. ${ }^{38}$ Rezultat toga bila je, naravno, bespravna gradnja, jedna od najtrajnijih pratećih pojava jugoslovenske industrijalizacije i modernizacije. ${ }^{39} \mathrm{Na}$ terenima nepredviđenim za gradnju, podizane su porodične kuće ispod građevinskih standarda, bez odgovarajuće infrastrukture. U Kragujevcu je, tako, 1962. bilo 1.020 zgrada bespravno građenih van građevinskog rejona, a i u samom gradu čak $785 .{ }^{40}$ Godine 1973. osnovana je Direkcija za urbanizam i izgradnju Kragujevca koja je 1974. uradila izmene i dopune GUP-a, „Kragujevac 1974-1977“. To je bio pokušaj da se u granicama mogućnosti isplanira kratkoročno urbanistički razvoj grada u naredne tri godine, kada je trebalo usvojiti novi GUP. ${ }^{41}$ Osma decenija 20. veka predstavlja vrhunac razvoja kragujevačke industrije, grada kao i jugoslovenske privrede u celini. Posle svetske naftne krize iz 1979. godine, nastupile su krizne godine $u$ Jugoslaviji (visoka zaduženost, devalvacije valute, nestašice) što je dovelo do usporavanja procesa industrijalizacije i modernizacije. ${ }^{42} \mathrm{Na}$ osnovu dotadašnjeg razvoja, donet je 1980. GUP „Kragujevac 2000”, za teritoriju od 13.300 ha, a za građevinsko zemljište bilo je predviđeno preko 8.500 ha. Međutim, trendovi iz prethodne decenije nisu se nastavili, i rast kako industrije, tako i grada, počeo je da stagnira. ${ }^{43}$

\footnotetext{
${ }^{36}$ Истио, 230-232.

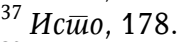

${ }^{38}$ Истио, 237, 194, 249.

${ }^{39}$ O tome: Ljubinko Pušić, „Gradovi kao kradena roba“, Limes plus, 2, (2005), 111119; Bespravna gradnja i njena legalizacija. Zbornik radova (Novi Sad: Pravo, 1997).

40 В. Трифуновић, н. g., 172.

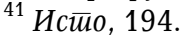

${ }^{42}$ D. Bilandžić, $n$. d., 484-488.

${ }^{43}$ Godine 1991. urađen je novi Generalni urbanistički plan „Kragujevac 2005“,
} u kojem je područje GUP-a smanjeno na 7.606 ha, a građevinski rejon na 5.570 ha. Godine 1996. u Kragujevcu je građevinsko zemljište svedeno na 4.250 ha. В. Трифуновић, н. g., 255. 


\section{Stambena izgradnja i prekid kontinuiteta sa gradskim nasleđem}

Nagli uspon fabrike pokrenuo je stambenu izgradnju do tada neviđenih razmera. Građevinsko zemljište Kragujevca nacionalizovano je 1958, kada je donet Zakon o nacionalizaciji najamnih zgrada i građevinskog zemljišta. Zemljište je tada prešlo u državnu svojinu, ali je bila predviđena eksproprijacija, do čijeg izvršenja je zemljište bilo u rukama dotadašnjih vlasnika. Površina građevinskog rejona tada je iznosila 1.960 ha. ${ }^{44}$ Od 1953. do 1973. izgrađeno gradsko zemljište raslo je tempom od oko 150 ha godišnje, pa se tokom 1970-ih godina gradilo na teritoriji od 3.500 ha, što je daleko prevazilazilo površinu građevinskog rejona. ${ }^{45}$ Zato je građevinski rejon proširen sa 1960 ha na 6.780 ha, generalnim planom iz 1974 („Kragujevac 1974-1977“). ${ }^{46}$ Tokom narednih godina još nekoliko hiljada hektara zemljišta prešlo je iz privatne u društvenu svojinu, što je omogućilo dalju izgradnju stambenih i drugih objekata. ${ }^{47}$ Nova stambena naselja u Kragujevcu Prodor, JNA, Banja Luka, Crvena zastava, E-20, Bagremar 1 i 2 - nastala su od 1960-ih godina upravo zbog razvoja automobilske industrije, radi rešavanja stambenog pitanja zaposlenih u Zavodima "Crvena zastava“. Pored opštinskog stambenog preduzeća, Zavodi „Crvena Zastava“ su imali i sopstveni stambeni fond i stambeno preduzeće, i u okvirima datih, promenljivih mogućnosti, rešavali stambeno pitanje svojih radnika. Tokom 1960-ih Zavodi su finansirali izgradnju naselja Bagremar 1 i Bagremar 2. Bagremar 1 je podignut pored Stare radničke kolonije, kao niz prizemnih, slobodno stojećih stambenih objekata, okruženih vrtovima, a Bagremar 2 je naselje višespratnica. ${ }^{48}$

Period najvećeg razvoja fabrike automobila obeležen je ogromnim porastom stambenog fonda u gradu, ali i velikom nestašicom stanova, jer gradnja nije mogla da prati brz tempo doseljavanja. Stanovanje je bio jedan od najkrupnijih socijalnih i ekonomskih problema. Kragujevac je u 19. veku imao 2.150 porodičnih prizemnih kuća, da bi 1975, u vreme vrhunca razvoja fabrike automobila, imao 32.500 stanova. Istovremeno, u odnosu na broj

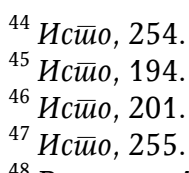

${ }^{48}$ Bagremar 1 je nova interpretacija Stare radničke kolonije, odnosno nemačke teorije Siedlung-a (što bolje iskoristiti prostor da bi što više nezbrinutih dobilo stambeni prostor). Bagremar 2 je zapadno od Centralne radionice, investitor je takođe Zastava, a to su višespratnice gde se stanovima prilazi sa galerija, i to je prvi takav slučaj u Kragujevcu, zasnovan na iskustvima Stare radničke kolonije, odnosno na evropskom iskustvu iz 1920-ih. Nisu bila predviđena GUP-om 1961, već su ušla u Reviziju GUP-a koju je počeo da radi

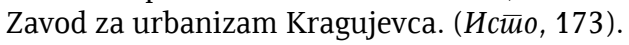


porodica nedostajalo je još oko 4.000 stanova. ${ }^{49}$ Radnici pristigli sa sela i iz raznih delova zemlje, rešavali su svoje stambeno pitanje uglavnom bespravnom gradnjom na periferiji, izvan građevinskog rejona. Tako je npr. 1971. nestašica stanova u centru bila daleko veća nego na periferiji (u gradu je nedostajalo 3.276 stanova, a na periferiji samo 246). ${ }^{50}$ Stambeni fond grada uvećan je od 1950-ih do 1990-ih oko šest puta: od 6.662 stana u 1954, do $35.867 \mathrm{u} 1989 .^{51}$

Masovna izgradnja stanova dovela je do širenja grada „u visinu“, do izgradnje višespratnica koje su bitno promenile tradicionalan izgled grada. Neposredno pre pokretanja automobilske industrije, 1950. godine, struktura stambenih zgrada u Kragujevcu je bila sledeća: 6.393 prizemne zgrade, 213 jednospratnih, 18 zgrada $\mathrm{P}+2$ i samo dve višespratne zgrade. ${ }^{52}$ Po tada važećem GUP-u, stanovanje je bilo predviđeno uglavnom $\mathrm{u}$ prizemnim zgradama, a samo u centru su se mogle graditi zgrade sa dva do tri sprata. ${ }^{53}$ Zbog velike potražnje za stanovima, lokalne vlasti su vršile izmene postojećeg GUP-a između 1959. i 1962, pa su tako nastala naselja kolektivnih stambenih zgrada (Prodor, JNA, Crvena zastava, Banja Luka, E-20, Kod Bolnice i druga), a omogućeno je izmenama plana, i postavljeno kao prioritet, da se u centru podižu zgrade visine do 14 spratova. ${ }^{54}$ Od sredine 1960 -ih do kraja 1970-ih gradnju u Kragujevcu obeležili su soliteri - u naselju JNA, u Prodoru, u Lepenici 1 i 2 (kule od 15 spratova), korpus solitera Zavoda "Crvena zastava" iz 1969, na prilazu industrijskoj zoni i, konačno, soliteri „Ipsilon“ u Erdogliji 1978. Kasnije su građene zgrade sa više spratova povezane u blokove. ${ }^{5}$

Razvoj industrije doveo je u razvoju grada do još jedne značajne pojave - stvaranja gradske aglomeracije (stapanja okolnih naselja sa gradom). Kragujevačka opština je, posle izgradnje nove fabrike automobila 1962. i ubrzanja proizvodnje, pokrenula 1964. postupak za izmenu i dopunu postojećeg GUP-a i za izradu prostornog plana opštine. Odlučeno je da se rubne zone grada zbog velikog doseljavanja pretvaraju u satelitska naselja. ${ }^{56}$ Ideja je bila da se grade fabrički pogoni u susednim opštinama, iz kojih je uglavnom dolazila radna snaga u fabriku (Knić, Batočina, Rača,

${ }^{49}$ Истй $0,230$.

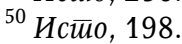

51 Tabela 29-17, Zgrade u 1954, SG 1956; Tabela 4-4, Stambena izgradnja i stambeni fond u 1989, SG 1990.

52 В. Трифуновић, н. g., 149.

${ }^{53}$ Ис $\bar{u} 0,155$.

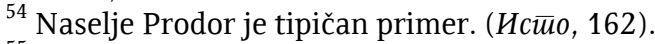

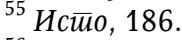

${ }^{56}$ Navedeno je deset takvih naselja: Petrovac, Desimirovac, Jovanovac, Ilićevo,

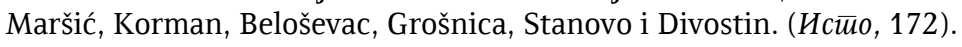


Topola), da se tamo stimuliše urbanizacija i tako smanji pritisak doseljavanja u grad. ${ }^{57}$ Proširen je građevinski rejon, predviđena prigradska zona i određena su satelitska naselja koja treba da uđu u taj prošireni rejon. ${ }^{58}$ Tamo je bila predviđena jeftinija individualna gradnja. Planirano je i proširenje stambene zone u centralnom naselju. Ona je povećana za 85,5 ha na račun zelenih površina, koje su smanjene za $30 \%{ }^{59}$ Naročito je zelena površina smanjena iza Skupštine, gde je locirano naselje JNA. Međutim, ovo smanjenje zelenih površina u centralnom naselju, ne predstavlja istovremeno i ukupno smanjenje zelenih površina u rejonu grada. Prema statistici, uređene zelene površine grada, sigurno i zbog stapanja sa okolnim naseljima, konstantno su, u posmatranom periodu, zauzimale sve veću površinu (od ukupno 672 ha u 1954, do 2.810 ha u 1990). ${ }^{60}$

Šezdesetih godina bilo je planirano nekoliko naselja za individualnu gradnju. U tom smislu, kao eksperiment su poslužila naselja Bresnica i Bagremar. Bresnica 1 je sagrađena početkom te decenije izvan područja građevinskog rejona, kao što je bio slučaj i sa Starom radničkom kolonijom od pre Drugog svetskog rata. ${ }^{61}$ To je bila planska četvrt jednoporodičnih kuća, između Metinog brda i starog puta za Jagodinu, koja se sastojala od 25 blokova od po 20-25 građevinskih parcela. Od infrastrukture imala je samo vodovod i struju (bez dalekovoda visokog napona), a planirane su javne površine - centar, škola, obdanište, pijaca i stadion, kao i skver sa zelenom površinom za park (koji nije realizovan do kraja 20. veka). Ovakva vrsta naselja odgovarala je potrebama većine doseljenih radnika koji nisu mogli da dobiju stan u gradu. To je bilo radničko naselje, koje je nastajalo postepeno, finansirano individualno uz pomoć bankarskih kredita. ${ }^{62}$

Tokom 1960-ih i 1970-ih godina prigradska naselja prerastaju u urboaglomeraciju. Na spojevima gradskog jezgra sa prigradskim naseljima, tzv. rubnim zonama, odvijala se intenzivna transformacija ruralnog prosto-

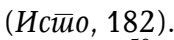

${ }_{58}^{57}$ Истио $, 172,178$.

58 Petrovac, Jovanovac, Maršić-Ilićevo, Teferič, Trmbač, Beloševac i Stanovo.

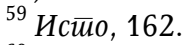

60 Tabela 29-19, Gradsko zelenilo u 1954, SG 1956; Tabela 4-15, Ulice, trgovi, zelene površine i pijace krajem 1990, SG 1991.

${ }^{61}$ Danas se ovo naselje naziva „Nova kolonija“. Nastalo je u periodu od 1936. do 1938, po projektu arh. Mihajla Radovanovića, kao „vrtno naselje“, koje je tada u Evropi i SAD bio popularan vid rešavanja stambenog pitanja radnika. Naselje je zadovoljavalo potrebe radnika i njihovih porodica. Imalo je oko 250 tipskih porodičnih kuća sa dvorištima, bogatim zelenilom, ali sa nedostatkom pratećih sadržaja, od kojih je do danas sačuvan dom za priredbe i fizičku kulturu, poznat kao „Sokolana“. (Nova kolonija http://www.gtokg. org. rs/sr/arhitektura3.php, (pristupljeno 5. 4. 2016). O tome: Војислав Бојовић, Драган Обрадовић, Сйара раяничка колонија 1929-1999 (Крагујевац: Нова светлост, 1999).

62 В. Трифуновић, н. g., 172. 
ra u urbani. U tim zonama stanovništvo je raslo brže nego u centralnim, a taj rast se potpuno poklapao sa rastom zaposlenih u Zavodima „Crvena zastava“. Gustina naseljenosti je, naravno, bila veća u centralnom naselju nego u rubnim područjima. Tako je krajem 20. veka Kragujevac imao centralno naselje od 2.000 ha površine i 100.000 stanovnika, i periferna naselja od 2.600 ha površine i oko 80.000 stanovnika. Broj naselja u rubnim delovima povećan je od dva u 1953. godini na šesnaest u 1971, i kasnije. Urbano zemljište raslo je dvostruko brže od rasta populacije, i to dvostruko više $u$ rubnim zonama (2.600 ha) nego u centralnim (1.350 ha). Opština Kragujevac u 1953. obuhvatala je jedan grad i 64 seoska naselja, a 1978. grad u vidu urboaglomeracije sa 17 naselja, i 48 seoskih naselja. Rezultati urbanizacije Kragujevca u vreme razvoja automobilske industrije su sledeći: stanovništvo je poraslo četiri puta, izgrađena teritorija osam puta, a 16 seoskih naselja sraslo je sa gradom $u$ vidu aglomeracije. ${ }^{63}$

Kragujevac je uključio u savremene evropske tokove urbanističkog planiranja i arhitekture, paralelno sa razvojem automobilske industrije i modernog planiranja industrijskog kompleksa. Došlo je do prekida kontinuiteta sa nasleđem i staro jezgro grada je trebalo da bude preoblikovano po principima modernizma. Značajni objekti zdravstva, socijalnog standarda, turizma, kulture i obrazovanja izgrađeni su tokom 1960-ih: Gradska skupština, Gradski dom, Mašinski fakultet, Viša pedagoška škola, Studentski dom, Klinički centar, hotel „Kragujevac“. Tokom 1970-ih godina nešto je intenziviran rast tercijarnih delatnosti (koje su dosta zaostajale iza stambene izgradnje), formiran je novi centar grada i urbanističko planiranje promenilo je obrazac u pravcu modernizma. Univerzitet „Svetozar Marković", osnovan 1976, nastao je upravo iz potrebe školovanja kadrova za kragujevačku industriju, čime je ovaj grad dobio još jednu dimenziju razvoja, kao univerzitetski centar. ${ }^{64}$

\section{Tercijarni sektor $\mathrm{i}$ infrastruktura}

Nagli i skokovit razvoj industrije i gradskog tkiva, posebno stambenog prostora, nije bio na odgovarajući način praćen u dva veoma važna sektora - u tercijarnom sektoru i infrastrukturi. U Kragujevcu je tokom 1960ih godina zona industrije i, posebno, kolektivnog stanovanja, dominirala nad svim ostalim sadržajima. Tako je $u$ naselju Prodor sagrađeno oko $53.000 \mathrm{~m}^{2}$ stambenog prostora, a samo oko $2.000 \mathrm{~m}^{2}$ prostora za trgovinu i ugostiteljstvo. Ekstenzivno naseljavanje van građevinskog rejona dovelo je do neravnoteže među funkcionalnim zonama u gradu, na štetu trgovine,

\footnotetext{
${ }^{63}$ Истио, 260-262.

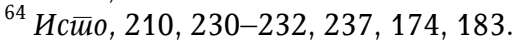


kulture, zdravstva i obrazovanja. ${ }^{65}$ Ovo je, međutim, tipična prateća pojava socijalističke industrijalizacije, $\mathrm{u}$ kojoj tercijarni sektor zaostaje za razvojem industrije. $^{66}$

Kada je reč o infrastrukturi, ona je bila povezana sa regionalnim i državnim mrežama, ali je znatno zaostajala u prigradskim naseljima. Izgradnja komunalne infrastrukture nije mogla da prati brz tempo širenja naselja i formiranje urbane aglomeracije. Sve do Drugog svetskog rata komunalna infrastruktura je pratila razvoj grada, dok je od pokretanja automobilske industrije počela znatno da zaostaje za potrebama naglo naraslog grada i industrije.

Osnovni infrastrukturni problem grada bilo je vodosnabdevanje, i to još od sredine 19. veka kada je naselje počelo da se razvija, uz Topolivnicu. Grad se nalazi na krečnjačkom terenu, i stoga je stalno trpeo od nedostatka vode. Početkom 20. veka izgrađen je Trmbaski vodovod, a tokom 1930-ih i akumulaciono jezero u Grošnici sa vodovodom koji je odatle snabdevao grad. ${ }^{67}$ Posle Drugog svetskog rata, deo Grošničke akumulacije je bio zasut, a tokom 1950-ih počeo je i novi ciklus razvoja industrije i grada, što je ponovo dovelo do problema sa vodosnabdevanjem. Kada je izgrađena nova fabrika automobila 1962, povećan je kapacitet jezera i izgrađena je 1964. mala akumulacija na Dulenskoj reci, ali se sa tim radovima kasnilo, što je izazvalo veliki nedostatak vode u gradu i u fabrici. ${ }^{68}$ Zato je raspisan zajam, pa je na taj način u periodu od 1966. do 1969. izgrađen Moravski vodovodni sistem (građani su uplatili 5,6 miliona, a preduzeća 4,7 miliona dinara). ${ }^{69}$ Grad Kragujevac je finansirao izgradnju druge faze Moravskog vodovodnog sistema uz samodoprinos građana od 48,6 miliona dinara. Konačno, 1984. realizovan je vodoprivedni sistem Gruža. ${ }^{70} \mathrm{U}$ vreme uspona fabrike automobila, vodovodna mreža je produžena sa 54 km u 1954, na 133 km u 1976. godini. Broj priključaka na vodovodnu mrežu uvećan je više puta - od 1.483 u 1954, do 9.389 u 1976. Udeo industrije u potrošnji vode porastao je u istom periodu (npr. prema podacima iz 1956, u ukupnoj potrošnji vode od $3.028 \mathrm{~m}^{3}$, na domaćinstva je spadalo $1.880 \mathrm{~m}^{3}$, dok je po podacima iz 1976 . domaćinstvima isporučivano $2.687 \mathrm{~m}^{3}$, a privredi $6.698 \mathrm{~m}^{3}$ ). Izgradnja kanalizacije je $\mathrm{u}$ istom periodu bila još intenzivnija - od 4,2 km u 1954, do $78 \mathrm{~km} \mathrm{u}$ 1976. godini. ${ }^{71}$

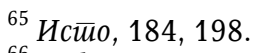

${ }^{66}$ Videti: Janos Kornai, The Socialist System. The Political Economy of Communism (Princeton (NJ): Princeton University Press, 1992), 165-199.

67 Ж. Спасић, н. g., 273-282.

${ }^{68}$ В. Трифуновић, н.g., 174.

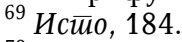

${ }^{70}$ Исйо $, 188,206$.

${ }^{71}$ Tabela 29-14, Gradski vodovod i kanalizacija u 1954, SG 1956; Tabela G - 17, Javni vodovod u 1956, SG 1957; Tabela 4-13, Javni vodovod i kanalizacija u 1976, SG 1977. 
Drugi veliki infrastrukturni problem grada $\mathrm{u}$ posleratnom periodu bio je nedostatak autoputa. Početkom 1970-ih Kragujevac je bio jedini grad u Jugoslaviji koji nije imao ne samo autoput, već ni put prvog reda. Saobraćajna izolacija grada bila je u velikom neskladu sa činjenicom da je industrija bila uključena u međunarodnu podelu rada. Izgradnjom puta Kragujevac-Batočina 1965. grad je izašao na autoput. ${ }^{72}$ Stari put za Beograd povezan je sa autoputem 1975 . Od sredine 1960-ih razvijala se mreža puteva oko grada, i nastao je prsten oko gradskog centra. ${ }^{73}$ Do kraja 20. veka grad nije izašao na evropski koridor, i pitanje železničkog čvora nije rešeno. ${ }^{74}$

\section{Kraj razvojnog ciklusa u poslednjoj deceniji 20. veka}

U poslednjoj deceniji 20. veka, za proizvodnju automobila u Kragujevcu (i za industriju uopšte) došlo je i do drastičnog smanjenja domaćeg tržišta, usled raspada države, a zbog rata i međunarodne izolacije i do gubitka inostranih tržišta, što je automobilsku industriju dovelo do sunovrata. Proizvodnja je smanjena više od deset puta, a stepen iskorišćenja kapaciteta pao je na ispod 10\%. U periodu od 1990. do 2011. broj zaposlenih u ukupnoj industriji Kragujevca opao je za više od 28.000, odnosno 4,5 puta, što je $\mathrm{u}$ relativnom smislu najveći pad zaposlenosti u industriji u Srbiji. „Zastava automobili" imali su 2001. godine 11.364 zaposlena, da bi tokom narednih deset godina, posle preuzimanja fabrike od strane italijanskog "Fiata“ (2009), broj zaposlenih spao na 1.169. ${ }^{75}$

Razvoj grada dostigao je svoj vrhunac u prethodnom periodu, i od 1990-ih ušao je u period stagnacije. Što se tiče broja stanovnika, on se u prethodne dve decenije nije smanjivao. Naprotiv, došlo je i do priliva izbeglica iz BiH i Hrvatske, kao i interno raseljenih lica sa Kosova i Metohije, koji su se naseljavali uglavnom u okolnim naseljima i rubnim opštinama gradske aglomeracije. Krajem 20. veka Kragujevac je imao centralno naselje na oko 2.000 ha sa 100.000 stanovnika i periferna naselja sa oko 2.600 ha i oko 80.000 stanovnika. ${ }^{76}$ Od 1991. do 2006. zabeležen je na celoj teritoriji grada porast broja stanovnika, sa 176.354 u 1991, na 192.176 u $2006 .^{77}$

${ }^{72}$ В. Трифуновић, н. g., 189.

${ }^{73}$ Ис $\overline{\mathrm{u}} 0,191$.

${ }^{74}$ Исйо 206.

${ }^{75}$ Vladimir Mićić, „Deindustrijalizacija privrede grada Kragujevca i perspektive razvoja industrije", u: Stanje i perspektive ekonomskog razvoja grada Kragujevca. Zbornik radova, ur. Ljiljana Maksimović, Nenad Stanišić (Kragujevac: Ekonomski fakultet, 2014), $85-95,87$.

${ }^{76}$ В. Трифуновић, н. g., 262.

77 Demografija Kragujevca, https://sr.wikipedia. org/sr/Демографија_Крагујевца, (pristupljeno 5. 4. 2016). 


\section{IZVORI I LITERATURA}

- Ekonomska politika (1976)

- Statistički godišnjak Jugoslavije (1954, 1956, 1961, 1976, 1981, 1984, 1990, 1991)

- Бакић, Драгољуб. Пей векова Країујевиа. Члании и усйомене. Превоgи и uррейска. Крагујевац: Народна библиотека „Вук Караџић“, 1972.

- Bilandžić, Dušan. Historija Socijalističke Federativne Republike Jugoslavije. Glavni procesi 1918-1985. Zagreb: Školska knjiga, 1985.

- Bjelajac, Mile. „Vojska kao faktor modernizacije“. U: Srbija u modernizacijskim procesima 20. veka, 355-359. Beograd: Institut za noviju istoriju Srbije, 1994.

- Бојовић Војислав, Драган Обрадовић. Сйара раgниика колонија 19291999. Крагујевац: Нова светлост, 1999.

- Brunnbauer, Ulf. „Dimitrovgrad. Eine sozialistische Stadt in Bulgarien“. In: Urbanisierung und Stadtentwicklung in Suedosteuropa vom 19 bis zum 21 Jahrhundert, hrsg. von Thomas M. Bohn und Marie Janine Calic, 197-221. Muenchen - Berlin: Suedosteuropa-Gesellschaft, 2010.

- Gašić, Ranka. „Urbanizacija međuratnog Beograda. Primer naselja 'Kotež Neimar'“. Istorija 20. veka, br. 2, (2009), 53-66.

- Gašić, Ranka. „Problemi teritorijalnog širenja Beograda između dva svetska rata“. Istorija 20. veka, br. 3, (2010), 57-68.

- Halpern, Manfred. „Middle Eastern Armies and the New Middle Class“. In: The Role of the Military in Underdeveloped Countries, ed. John Johnson, 277-315. Princeton (NJ): Princeton University Press, 1959.

- Јанковић, Слободан. Зайиси о Засйави. Повоgом 140 їоgина раgа и 40 іоgина йроизвоgюе ауйомобила. Крагујевац: Застава, 1993.

- Kornai, Janos. The Socialist System. The Political Economy of Communism. Princeton (NJ): Princeton University Press, 1992.

- Macura, Vladimir. Čaršija i gradski centar: razvoj središta varoši i grada Srbije XIX i prve polovine XX veka. Niš-Kragujevac: Gradina-Svetlost, 1984.

- Mićić, Vladimir. „Deindustrijalizacija privrede grada Kragujevca i perspektive razvoja industrije“. U: Stanje i perspektive ekonomskog razvoja grada Kragujevca. Zbornik radova, ur. Ljiljana Maksimović, Nenad Stanišić, 8595. Kragujevac: Ekonomski fakultet, 2014.

- Pušić, Ljubinko. „Gradovi kao kradena roba“. Limes plus, br. 2, (2005), 111-119. 
- Спасић, Живомир. Век усйона Краі̄ујеви,а. Прилози истиорији їраgа и околине. Крагујевац: Светлост, 1978.

- Трифуновић, Верољуб. Урбанизам Краі̄ујевиа. 20. век. Књиі̄a йрва. Пepuog og 1878. go 1974. Крагујевац: Дирекција за урбанизам и изградњу Крагујевца, 2004.

- Vuksanović Anić, Draga. „Urbanistički razvitak Beograda u periodu između dva svetska rata (1919-1941)“. U: Istorija 20. veka, Zbornik radova IX, 447-510. Beograd: Institut za savremenu istoriju, 1968.

- Company town. https://en.wikipedia. org/wiki/Company_town. (pristupljeno 5. 4. 2016).

- Demografija Kragujevca. https://sr.wikipedia. org/sr/Демографија_Крагујевца, (pristupljeno 5. 4. 2016).

- Nova kolonija. http://www.gtokg.org. rs/sr/arhitektura3.php. (pristupljeno 5. 4. 2016).

- Pirelli Tower. https://en.wikipedia. org/wiki/Pirelli_Tower. (pristupljeno 5. 4. 2016).

- Тодор Селесковић, https://sr.wikipedia. org/sr/Тодор_Селесковић,_pristupljeno 5. 4. 2016).

Ranka Gašić

FACTORY AND TOWN: THE AUTOMOBILE INDUSTRY AND THE URBAN DEVELOPMENT OF KRAGUJEVAC 1953-1991

\section{Summary}

Kragujevac was an industrial town from the earliest period of the modern history of Serbia. Its military indusrial complex was situated in the close proximity of the downtown area. The development of industry was given its greatest impetus in the 1960s with the establishment of the automobile industry and the erection of the automobile factory in 1962. In the mid 1970s the "Crvena zastava" factory contributed by $80 \%$ to the economy of Kragujevac and its surroundings. The large investments in the automobile industry in the 1960s and 1970s triggered the speedy development of the town and of the building activities on such a scale that urban planning simply could not keep pace with spontaneous growth of the town dwelling area. The result was illegal building, one of the most characteristic and durable phenomena of the Yugoslav industrialization and modernization. The dwelling areas in the town were spreading fast from 1953 to 1973 
(the period of the fastest growth of car industry), by cc.150 ha per annum. Multy-storey residential buildings have changed the traditional townscape. However, they could not be erected soon enough to provide accommodation for a neverending influx of population. The fast growing car industry led to another important feature of the development of Kragujevac - the creation of large urban agglomeration, by merging surrounding villages with the town. Since the 1960s the industry and dwelling zones were predominant in Kragujevac, in comparison with communal municipal infrastructure, which was seriously lagging behind (especially the water supply system and the road network). Kragujevac and its industry (like the Yugoslav economy as a whole) have reached the peak of their development in the 1970s. After the global oil crisis in 1979 the whole process of Yugoslav industrialization was brought to a halt, and the car industry in Kragujevac, as well as the town itself entered the phase of stagnation. However, regardless of the decline of car industry, the influx of population did not stop, but continued in a different form. Instead of workers in search of jobs, the refugees from Bosnia and Croatia, and the internally displaced persons from Kosovo kept coming to the Kragujevac during the 1990s wars in ex Yugoslavia.

KEYWORDS: Kragujevac, car industry, „Crvena zastava“, urbanization

\section{DIE FABRIK UND DIE STADT: EINFLUSS DER AUTOINDUSTRIE AUF DIE STADTENTWICKLUNG UND URBANISIERUNG VON KRAGUJEVAC 1953-1991}

\section{Zusammenfassung}

Kragujevac war eine Industriestadt aus der frühesten Zeit der modernen Geschichte Serbiens. Seine militärische indusrielle Komplex wurde in der Nähe der Innenstadt gelegen. Die Entwicklung der Industrie wurde seine stärksten Impulse in den 1960er Jahren mit der Gründung der Automobilindustrie und die Errichtung der Automobilfabrik im Jahr 1962. gegeben. In der Mitte der 1970er Jahre die „Crvena Zastava“ Fabrik hat um $80 \%$ für die Wirtschaft von Kragujevac und seine Umgebung beigetragen. Die großen Investitionen in der Automobilindustrie in den 1960er und 1970er Jahren löste die rasche Entwicklung der Stadt und die Bautätigkeiten in einem solchen Umfang, dass die Stadtplanung einfach nicht Schritt mit spontanen Wachstum der Stadt Wohnbereich halten konnte. Das Ergebnis war das Bilden von illegale Wohnungen, eines der charakteristischsten und dauerhafte Phänomene der jugoslawischen Industrialisierung und Moder- 
nisierung. Die Wohnbereiche in der Stadt wurden von 1953 bis 1973 (die Zeit des schnellsten Wachstum der Automobilindustrie) schnell verbreitet, von cc.150 ha pro Jahr. Mehrgeschossigen Wohngebäuden haben die traditionelle Stadtbild verändert. Allerdings konnten sie nicht schnell genug aufgestellt werden um Unterkunft für einen konstanten Zustrom von Bevölkerung zu bieten. Die schnell wachsende Automobilindustrie führte zu einem weiteren wichtigen Merkmal der Entwicklung von Kragujevac die Schaffung von großen urbanen Ballungsräume, durch die Einigung von den umliegenden Dörfern mit der Stadt. Seit den 1960er Jahren waren die Industrie und Wohnzonen vorherrschend in Kragujevac, im Vergleich zu kommunalen Infrastruktur, die ernsthaft zurückgeblieben war (vor allem die Wasserversorgung und das Straßennetz). Kragujevac und seine Industrie (wie die jugoslawische Wirtschaft insgesamt) haben den Höhepunkt ihrer Entwicklung in den 1970er Jahren erreicht. Nach der Ölkrise im Jahr 1979 wurde der gesamte Prozess der jugoslawischen Industrialisierung zum Stillstand gebracht, und die Automobilindustrie in Kragujevac, sowie die Stadt kamen in die Phase der Stagnation. Doch unabhängig von dem Rückgang der Automobilindustrie, hat der Zustrom von Bevölkerung nicht gestoppt, aber in einer anderen Form fortgesetzt. Statt der Arbeitnehmer auf der Suche nach Jobs, die Flüchtlinge aus Bosnien und Kroatien, und die Binnenvertriebenen aus dem Kosovo waren in den 1990er Jahren Kriege in Ex-Jugoslawien in die Kragujevac immigriert.

SCHLÜSSELWÖRTER: Kragujevac, Automobilindustrie, „Crvena zastava“, Urbanisierung 